\title{
Aplikasi Paperless Office dalam Implementasi Electronic Office Menggunakan Pendekatan Unified Modelling Language
}

\author{
Hamim Tohari ${ }^{1}$, Ahmad Kudhori ${ }^{2}$, Sundaru Guntur Wibowo ${ }^{3}$ \\ e-mail: ${ }^{1}$ htohari@pnm.ac.id, ${ }^{2}$ akudhori@ pnm.ac.id, ${ }^{3}$ sundaru.guntur@pnm.ac.id \\ 1,2,3Politeknik Negeri Madiun - Jl.Ring Road Barat-Manguharjo Madiun, Telp. 0351-452970 \\ Jurusan Komputer Akuntansi - Program Studi Komputerisasi Akuntansi
}

\begin{abstract}
Abstrak-Saat ini dan masa yang akan datang kebutuhan akan adanya sebuah aplikasi paperless office yang mampu menunjang implementasi electronic office (e-Office) akan terus diperlukan. Program Studi Komputerisasi Akuntansi Politeknik Negeri Madiun, hingga saat ini (saat penelitian ini dilakukan) belum menerapkan $e$-Office dalam kegiatan administrasi sehari-hari, khususnya dalam aktivitas surat-menyurat. Tujuan dari penelitian ini yaitu untuk mengetahui tahapan pada model incremental pada pembuatan Aplikasi Paperless Office (APO), dan untuk mengetahui kesesuaian APO dengan konsep paperless office. Metode yang akan digunakan di dalam perancangan dan pembuatan aplikasi ini yaitu model incremental dengan pendekatan Unified Medelling Language (UML). Penelitian ini menghasilkan sebuah aplikasi (APO) yang dapat menunjang dalam implementasi $e$-Office untuk manajemen surat menyurat di Program Studi Komputerisasi Akuntansi Politeknik Negeri Madiun.
\end{abstract}

Kata kunci: e-Office, paperless office, UML.

\section{Pendahuluan}

Hal yang menjadi fungsi pokok dari kantor adalah melaksanakan pekerjaan yang bersifat administrastif untuk menyiapkan data dan informasi bagi kepentingan organisasi dan kepentingan umum ${ }^{[1]}$. Kebutuhan akan informasi menjadi hal yang sangat vital dalam berbagai hal. Keberadaan media komunikasi yang efektif dan efisien untuk penyampaian informasi sangat diperlukan, agar terbentuk persamaan informasi antara pemberi pesan dengan penerima pesan. Salah satu media komunikasi di perkantoran yaitu dengan surat menyurat atau korespondensi menggunakan kertas. Lembar yang dibutuhkan untuk membuat surat tergantung banyaknya isi surat tersebut. Jika aktivitas surat menyurat di kantor sering dilakukan, maka sudah barang tentu akan meningkatkan pula kebutuhan kertas. Disamping itu, untuk keperluan perawatan dan penyimpanan suratsurat penting yang terus bertambah kuantitasnya, mengakibatkan pengeluaran biaya yang relatif cukup tinggi dalam hal penyediaan tempat dan sarana lainnya untuk penyimpanan dokumen berupa surat-surat tersebut.

Teknologi informasi yang diterapkan dalam sebuah kantor untuk mendukung kegiatan perkantoran diantaranya yaitu penerapan Electronic Office (e-office), yaitu suatu sistem yang berhubungan dengan kegiatan administrasi perkantoran secara daring, yang memusatkan komponenkomponen sebuah organisasi. Data dan informasi, serta komunikasi dibuat melalui media telekomunikasi [2].

Paperless Office memiliki peluang untuk memberikan peran dalam pelayanan administrasi yang lebih efektif dan efisien yang dapat mengurangi penggunaan kertas untuk kebutuhan surat menyurat dan pembuatan dokumen-dokumen lain pada sebuah kantor. Sistem Paperless Office juga dapat meningkatkan produktivitas dengan format digital, sehingga penyebaran informasi menjadi lebih mudah dan cepat. Paperless office merupakan suatu perwujudan lingkungan kerja dimana sedapat mungkin menghilangkan atau mengurangi penggunaan kertas dalam pekerjaan seharihari. Hal tersebut bisa dilakukan dengan adanya konversi dokumen dan kertas lainnya ke dalam bentuk digital [3]. Pemanfaatan paperless menjadi hal yang sangat efisien dalam kegiatan administrasi perkantoran untuk itu istilah "Paperless" dalam bidang administrasi perkantoran disebut dengan "Paperless Office". Paperless Office (PLO) menyediakan fitur pengelolaan surat, disposisi surat, pengelolaan memo, diskusi internal dan berita dimana memungkinkan juga adannya komunikasi yang interaktif dalam kolom komentar di beberapa kontennya [4]. Penerapan PLO bukan hal yang mudah, hal ini karena adanya 
konvergensi dari yang biasa berkomunikasi dan melakukan administrasi secara konvensional/manual menjadi digital, terdapat beberapa aspek yang harus diperhatikan, yaitu: (1) aspek SDM/pengguna, (2) aspek dokumen, (3) aspek sistem aplikasi, dan (4) aspek sosialisasi [4].

Model Incremental Process memakai urutan-urutan linear yang berulang dalam membangun suatu perangkat lunak. Seiring berjalan waktu pengerjaan, setiap urutan linear akan menghasilkan perkembangan dalam pengerjaan perangkat lunak yang kemudian dapat digunakan oleh pengguna [5]. Model incremental adalah "The incremental build life cycle model provides for progressive development of operational software, with each release providing added capabilities" [6]. Mengacu pada beberapa pendapat di atas, maka dalam hal ini dapat dinyatakan bahwa Incremental model merupakan suatu metode yang terdiri dari beberapa increment dengan manajemen sederhana dimana produk didesain, diimplementasikan, dan diuji secara bertahap (setiap modul akan ditambahkan bertahap) sampai produk dinyatakan selesai.

Electronic Office merupakan aplikasi kantor yang menggantikan proses administrasi secara manual menjadi proses berbasis elektronis dengan memanfaatkan fasilitas Local Area Network (LAN), maupun jaringan internet [7]. Sistem e-Office selain meminimalisasi penggunaan kertas (paperless), e-Office juga mempermudah penyimpanan dan pengolahan data di dalam suatu kantor karena data menjadi terpusat (centralized) dengan bantuan database sehingga data yang ada akan saling terhubung dan menjadi kesatuan utuh yang dapat memberikan informasi bagi pegawai kantor [2]. Merujuk pada beberapa pendapat tentang Electronic Office, dalam konteks ini Electronic Office dapat dinyatakan sebagai suatu sistem yang berhubungan dengan kegiatan administrasi, yang secara maya memusatkan komponen-komponen sebuah organisasi, di mana data, informasi dan komunikasi dilakukan secara elektronis melalui media telekomunikasi.

UML terdiri dari pengelompokan diagram-diagram sistem menurut aspek atau sudut pandang tertentu [8]. UML hanya berfungsi untuk melakukan pemodelan, jadi penggunaan UML tidak terbatas pada metodologi tertentu, meskipun pada kenyataannya UML paling banyak digunakan pada metodologi berorientasi objek [9]. Merujuk pada beberapa teori tersebut, maka dapat dinyatakan bahwa UML adalah suatu bahasa pemodelan berupa diagram-diagram yang dapat digunakan pada analisis dan perancangan sistem atau perangkat lunak.

Saat ini (pada saat penelitian ini dilakukan) sistem administrasi perkantoran di Program Studi Komputerisasi Akuntansi Politeknik Negeri Madiun (khususnya dalam hal manajemen surat menyurat) belum menerapkan e-office atau masih dilakukan secara manual tanpa menggunakan alat bantu aplikasi. Peneliti termotivasi untuk mengembangkan sebuah aplikasi paperless office sebagai alat bantu dalam penerapan electronic office. Adapun tujuan dari penelitian yakni untuk mengetahui tahapan dalam implementasi model incremental pada pembuatan sebuah Aplikasi Paperless Office (APO), dan untuk mengetahui kesesuaian APO dengan konsep e-Office.

\section{Metode Penelitian}

Pengembangan perangkat lunak akan dilakukan secara bertahap dengan melakukan penambahan fitur maupun fungsi pada setiap perangkatnya sedikit demi sedikit hingga perangkat lunak menjadi sempurna. Model Incremental dipilih karena dalam pengembangan sistem dapat dilakukan secara bertahap dan terus dilakukan penyesuaian oleh pengguna. Sehingga dapat meminimalisir ketidaksesuaian pengembangan perangkat lunak.

Sehingga, tahapan penelitian ini pun akan mengikuti tahapan yang digunakan pada model incremental, yaitu terdiri dari beberapa increment. Setiap increment terdiri dari kegiatan analysis, design, code, dan test sebagaimana ditunjukkan pada gambar 1 .

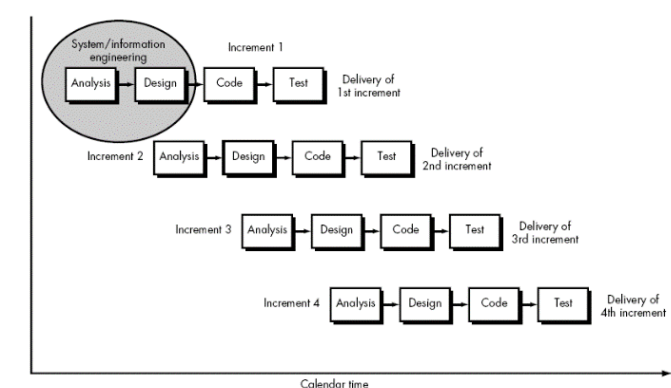




\section{Gambar 1. Model Incremental Sumber: [10]}

Penelitian ini diawali dengan menggunakan model incremental untuk melakukan perancangan dan pembuatan APO. Selanjutnya APO akan diuji cobakan ke dalam sistem e-Office yang ada di Program Studi Komputerisasi Akuntansi Politeknik Negeri Madiun, yang akan melibatkan seluruh tenaga SDM yang ada, yaitu dua orang tenaga kependidikan dan ketua program studi.

Sesuai dengan tujuan dari penelitian ini, maka akan dapat diketahui bagaimana tahapan pembuatan APO menggunakan model incremental, dan berdasarkan konsep e-Office maka akan dapat diketahui apakah APO sesuai dengan konsep e-Office tersebut yang dilihat berdasarkan aspek SDM, dokumen, sistem aplikasi, dan sosialisasi sebagaimana ditunjukkan pada gambar 2 .

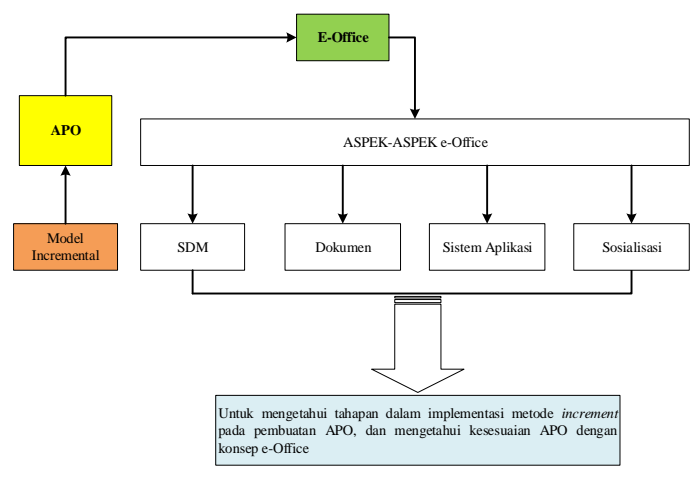

Gambar 2. Desain penelitian Sumber: desain peneliti

Penelitian ini dilaksanakan pada semester genap tahun akademik 2020-2021. Lokasi penelitian dilaksanakan di Program Studi Komputerisasi Akuntansi Politeknik Negeri Madiun.

Penelitian ini melibatkan pengelola Program Studi Komputerisasi Akuntansi Politeknik Negeri Madiun. Adapun subjek penelitian dalam penelitian ini terdiri dari tiga orang, yaitu Ketua Program Studi Komputerisasi Akuntansi, dan dua orang tenaga kependidikan.

\section{Hasil dan Pembahasan}

Berdasarkan pada hasil analisis kebutuhan sistem secara fungsional, maka pada tahap ini akan dilakukan desain sistem dari sistem APO. Adapun desain dilakukan menggunakan pendekatan UML, yang dalam hal ini desain sistem disajikan dalam bentuk use case diagram sebagaimana ditunjukkan pada gambar 3.

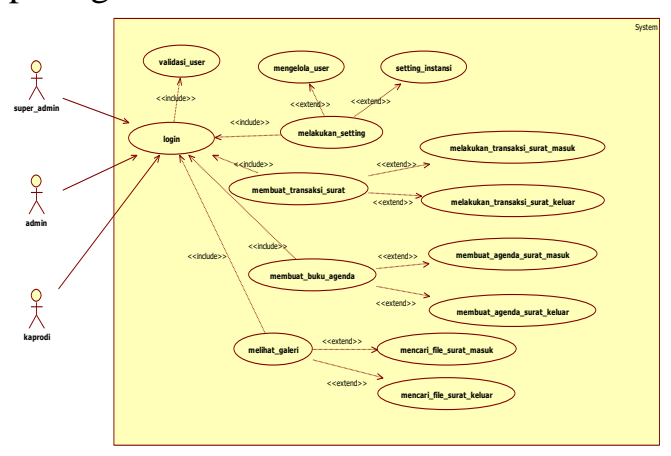

Gambar 3. Use case diagram sistem Sumber: desain peneliti

Aktor-aktor yang akan terlibat langsung di dalam sistem secara rinci didefinisikan sebagaimana terdapat pada tabel 1.

Tabel 1. Pendefinisian Aktor
\begin{tabular}{|c|c|l|}
\hline No & Aktor & \multicolumn{1}{|c|}{ Deskripsi } \\
\hline 1. & $\begin{array}{l}\text { Super } \\
\text { admin }\end{array}$ & $\begin{array}{l}\text { Aktor ini adalah orang } \\
\text { yang bertanggungjawab } \\
\text { dalam manajemen } \\
\text { sistem, dengan hak } \\
\text { akses penuh terhadap. }\end{array}$ \\
\hline 2. & $\begin{array}{l}\text { Admin } \\
\text { biasa }\end{array}$ & $\begin{array}{l}\text { Aktor ini adalah orang } \\
\text { yang ditunjuk sebagai } \\
\text { staf administrasi yang } \\
\text { menangani pengelolaan } \\
\text { surat menyurat, dengan } \\
\text { hak akses transaksi, } \\
\text { buku agenda, dan galeri } \\
\text { file. }\end{array}$ \\
\hline 3 & Kaprodi & $\begin{array}{l}\text { Aktor ini adalah Ketua } \\
\text { PRODI, dengan hak } \\
\text { akses transaksi, buku } \\
\text { agenda, dan galeri file. }\end{array}$ \\
\hline
\end{tabular}

Pendefinisian dari masing-masing use case diperlukan untuk dapat mengetahui dengan jelas proses dari masing-masing use case tersebut. Adapun secara rinci definisi dari use case dapat dilihat pada tabel 2.

Tabel 4.2 Pendefinisian use case
\begin{tabular}{|c|l|l|}
\hline No & Use Case & \multicolumn{1}{c|}{ Deskripsi } \\
\hline 1. & login & $\begin{array}{l}\text { Proses pemasukkan user } \\
\text { name dan password oleh } \\
\text { semua aktor untuk dapat } \\
\text { masuk ke dalam sistem }\end{array}$ \\
\hline
\end{tabular}




\begin{tabular}{|c|c|c|}
\hline No & Use Case & Deskripsi \\
\hline 2. & $\begin{array}{l}\text { validasi } \\
\text { user }\end{array}$ & $\begin{array}{l}\text { Proses validasi user } \\
\text { name dan password yang } \\
\text { dilakukan oleh sistem }\end{array}$ \\
\hline 3 & $\begin{array}{l}\text { melakukan } \\
\text { setting }\end{array}$ & \begin{tabular}{lcc} 
Proses & pemilihan & opsi \\
setting & yang & akan \\
dilakukan & oleh & super \\
admin & (administrator \\
sistem) & \multicolumn{2}{c}{} \\
\end{tabular} \\
\hline 4 & $\begin{array}{l}\text { mengelola } \\
\text { user }\end{array}$ & $\begin{array}{lr}\text { Proses pengelolaan data } \\
\text { dan hak akses } \text { user yang } \\
\text { meliputi operasi } & \text { CRUD } \\
\text { yang hanya } & \text { bisa } \\
\text { dilakukan oleh super } \\
\text { admin }\end{array}$ \\
\hline 5 & $\begin{array}{l}\text { setting } \\
\text { instansi }\end{array}$ & $\begin{array}{l}\text { Proses pengelolaan data } \\
\text { instansi yang meliputi } \\
\text { operasi CRUD yang } \\
\text { hanya bisa dilakukan } \\
\text { oleh super admin }\end{array}$ \\
\hline 6 & $\begin{array}{l}\text { membuat } \\
\text { transaksi } \\
\text { surat }\end{array}$ & $\begin{array}{lr}\text { Proses pemilihan opsi } \\
\text { transaksi pencatatan } \\
\text { surat-surat yang bisa } \\
\text { dilakukan oleh semua } \\
\text { user/aktor }\end{array}$ \\
\hline 7 & $\begin{array}{l}\text { membuat } \\
\text { transaksi } \\
\text { surat } \\
\text { masuk }\end{array}$ & $\begin{array}{l}\text { Proses pencatatan surat } \\
\text { masuk, yang meliputi } \\
\text { pencatatan nomor } \\
\text { agenda, asal surat, nomor } \\
\text { surat, isi ringkas dari } \\
\text { surat, kode klasifikasi, } \\
\text { indeks berkas, tanggal } \\
\text { surat, keterangan } \\
\text { (opsional), dan upload } \\
\text { file surat; yang bisa } \\
\text { dilakukan oleh semua } \\
\text { aktor, dengan aksi } \\
\text { simpan atau batal }\end{array}$ \\
\hline 8 & $\begin{array}{l}\text { membuat } \\
\text { transaksi } \\
\text { surat } \\
\text { keluar }\end{array}$ & $\begin{array}{l}\text { Proses pencatatan surat } \\
\text { keluar, yang meliputi } \\
\text { pencatatan nomor } \\
\text { agenda, asal surat, nomor } \\
\text { surat, isi ringkas dari } \\
\text { surat, kode klasifikasi, } \\
\text { indeks berkas, tanggal } \\
\text { surat, keterangan } \\
\text { (opsional), dan upload } \\
\text { file surat; yang bisa } \\
\text { dilakukan oleh semua } \\
\text { aktor, dengan aksi } \\
\text { simpan atau batal }\end{array}$ \\
\hline 9 & $\begin{array}{l}\text { membuat } \\
\text { buku } \\
\text { agenda }\end{array}$ & $\begin{array}{l}\text { Proses pemilihan opsi } \\
\text { pencetakan buku agenda } \\
\text { surat secara periodik (per }\end{array}$ \\
\hline
\end{tabular}

\begin{tabular}{|c|l|l|}
\hline No & Use Case & \multicolumn{2}{|c|}{ Deskripsi } \\
\hline & & $\begin{array}{l}\text { tanggal), yang bisa } \\
\text { dilakukan oleh semua } \\
\text { user/aktor }\end{array}$ \\
\hline 10 & $\begin{array}{l}\text { membuat } \\
\text { buku } \\
\text { agenda } \\
\text { surat } \\
\text { masuk }\end{array}$ & $\begin{array}{l}\text { Proses pencetakan buku } \\
\text { agenda surat masuk } \\
\text { secara periodik (per } \\
\text { tanggal), yang bisa } \\
\text { dilakukan oleh semua } \\
\text { user/aktor }\end{array}$ \\
\hline 11 & $\begin{array}{l}\text { membuat } \\
\text { buku } \\
\text { agenda } \\
\text { surat } \\
\text { keluar }\end{array}$ & $\begin{array}{l}\text { Proses pencetakan buku } \\
\text { agenda surat keluar } \\
\text { secara periodik (per } \\
\text { tanggal), yang bisa } \\
\text { dilakukan oleh semua } \\
\text { user/aktor }\end{array}$ \\
\hline 12 & $\begin{array}{l}\text { melihat } \\
\text { galeri } \\
\text { pencarian file surat yang } \\
\text { bisa dilakukan oleh } \\
\text { semua user/aktor }\end{array}$ \\
\hline 13 & $\begin{array}{l}\text { Proses pencarian file } \\
\text { surat masuk yang bisa } \\
\text { dilakukan oleh semua } \\
\text { user/aktor }\end{array}$ \\
\hline file surat \\
masuk
\end{tabular}

Desain database juga dilakukan menggunakan pendekatan UML, yang dalam hal ini berupa class diagram yang dapat dilihat pada gambar 4 .

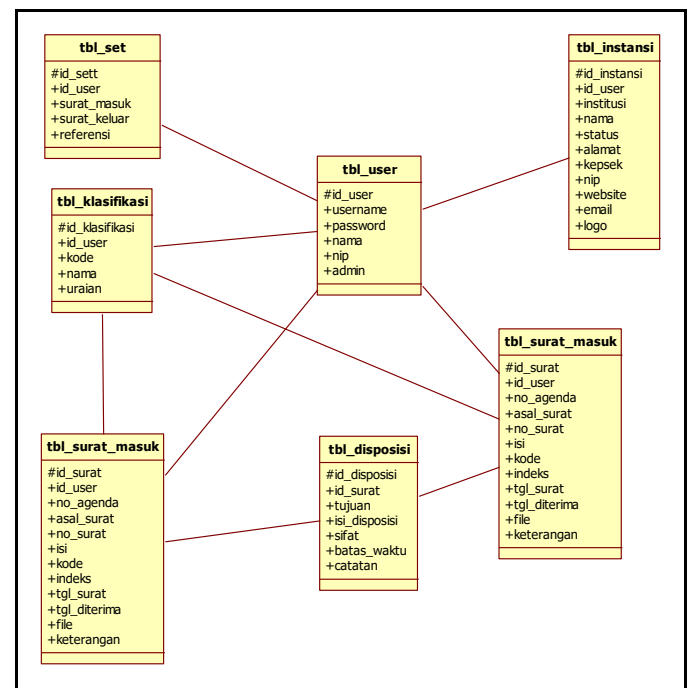

Gambar 4.2. Class diagram dari app_surat.sql Sumber: desain peneliti

Implementasi (tahap code) dilakukan berdasarkan desain sistem yang telah dibuat, 
yakni dengan melakukan coding untuk membuat interface yang akan digunakan oleh masing-masing use case.

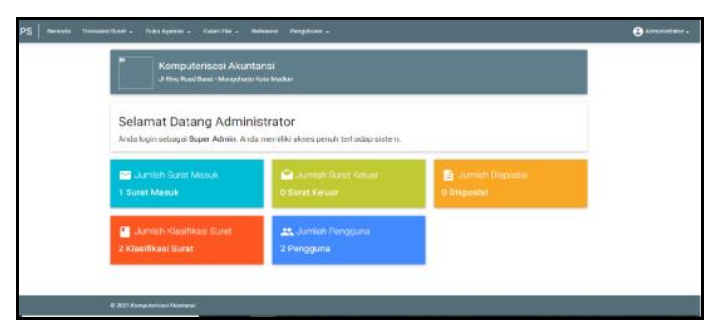

Gambar 5. Interface halaman super admin Sumber: desain peneliti

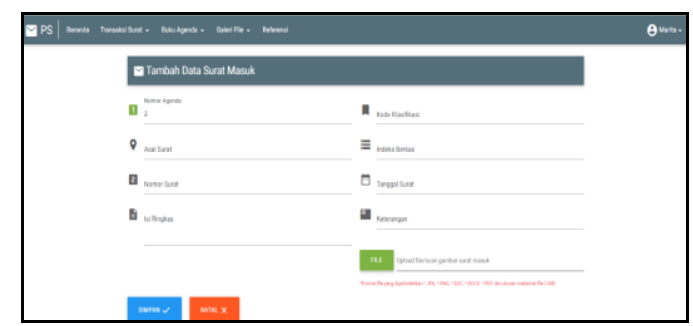

Gambar 6. Interface halaman transaksi tambah surat masuk

Sumber: desain peneliti

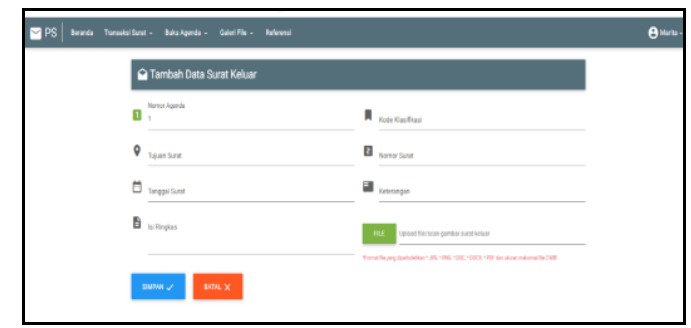

Gambar 6. Interface halaman transaksi tambah surat keluar

Sumber: desain peneliti

Tahap pengujian dilakukan untuk mengetahui kesesuaian aplikasi dengan kebutuhan sistem secara fungsional. Pengujian aplikasi dilakukan menggunakan metode black-box testing. Adapun dari tahap pengujian aplikasi (APO) diperoleh hasil valid untuk semua use case.

Penelitian ini sejalan dengan penelitian yang berjudul "Sistem Informasi e-Office sebagai Pendukung Progam Paperless Korespondensi Perkantoran (Studi Kasus: Bagian Administrasi Akademik Akademi Komunitas Semen Indonesia Gresik)" [2], menunjukkan hasil bahwa aplikasi e-Office berupa surat masuk dan surat keluar serta disposisi memudahkan pegawai mengurus administrasi perkantoran khususnya dokumen persuratan dan korespondensi sehingga surat dapat diproses secara cepat dan efisien. Demikian juga juga dengan penelitian yang berjudul "Penerapan Paperless sebagai Media Komunikasi Digital" [4], menunjukkan hasil bahwa Paperless Office memudahkan dalam kegiatan administrasi dan komunikasi baik karyawan maupun dosen SDM yang melek internet dan komputer, serta pimpinan universitas terkait merupakan faktor penting dalam penerapan Paperless Office.

\section{Kesimpulan}

Berdasarkan pada hasil dari penelitian ini, maka dapat disimpulkan bahwa: pertama, rancang bangun APO menggunakan metode incremental dapat dilakukan dalam empat tahap dalam satu increment, yaitu (1) analysis, (2) design, (3) code, dan (4) test; ke dua, mengacu pada hasil analisis kebutuhan sistem dan hasil uji coba aplikasi yang telah dilakukan, APO telah memenuhi keempat aspek dari konsep paperless office, yaitu (1) keberadaan SDM, (2) dokumen, (3) sistem aplikasi, dan (4) sosialisasi. Maka dengan demikian dapat dikatakan bahwa APO sudah sesuai dengan konsep paperless office.

\section{Daftar Pustaka}

[1] Sugiarto, TW dan Agus. 2014. Manajemen Kearsipan Eletronis. Yogyakarta : Gava Media.

[2] Mulyono, T. 2018. Pendukung Program Paperless Korespondensi Perkantoran (Studi Kasus: Bagian Administrasi Akademik-Akademi Komunitas Semen Indonesia Gresik). ECNOSCIENZA 2(2): 108-122.

[3] Riadi, Muhammad Taufik. 2011. Paperless Office Teknik Geodasi FT UGM. Plogeodesi.ugm.ac.id/download/petunjukpenggunaan-PLO-Geodesi-FT-UGM2011_5.pdf (diakses 28 Januari 2015).

[4] Iskandar, TP., \& Wardiani, W. 2020. Penerapan Paperless Sebagai Media Komunikasi Digital, Jurnal Ilmiah LISKI. 6(2): 93-101.

[5] Pressman, Roger S. 2010. Rekayasa Perangkat Lunak. Yogyakarta: Andi.

[6] Arsia R, Azdy A.R. 2016. Implementasi Incremental Model Pada Sistem Informasi Penyewaan Barang dan Jasa PT. Sriwijaya Indah Persada Palembang. 
Teknik Informatika STMIK PalComTech Palembang.

[7] Dewandaru, DS. 2013. Pemanfaatan Aplikasi E-Office untuk Mendukung Penerapan E-Goverment dalam Kegiatan Perkantoran (Studi Kasus: PUSLITBANG Jalan dan Jembatan). Seminar Nasional Teknologi Informasi dan Komunikasi 2013 (SENTIKA 2013). Yogyakarta.

[8] Tohari, H. 2014. Astah: Analisis serta Perancangan Sistem Informasi melalui Pendekatan UML. Yogyakarta: Andi.
[9] Rosa dan Shalahuddin. 2014. Rekayasa Perangkat Lunak Struktur dan Berorientasi Objek. Bandung: Informatika.

[10] Putri, Denti D. 2018. Pengembangan Learning Management System Menggunakan Framework Codeigniter Dan Angularjs Di PT. XYZ. Jurnal Sistem Informasi (Journal of Information System), 14(1). 